\title{
Role of immunoblotting in the diagnosis of culture negative and enterococcal endocarditis
}

\author{
J P BURNIE, M HOLLAND, * RUTH C MATTHEWS, W LEES \\ From the Departments of Medical Microbiology, St Bartholomew's Hospital and *The London Hospital
}

SUMMARY Serum samples from patients with endocarditis and septicaemia due to Enterococcus faecalis, Enterococcus faecium, Streptococcus bovis, and Streptococcus sanguis were immunoblotted against antigenic extracts from all four species. In $E$ faecalis endocarditis there was a strong IgM response to $E$ faecalis antigenic bands of $112,88-90$, and $45-47 \mathrm{Kd}$ and a strong IgG response to 88-90 and 45-47 Kd bands. In E faecium endocarditis there was a pronounced IgG response to an $E$ faecium band of $82-90 \mathrm{Kd}$. For $S$ bovis endocarditis, there was a strong IgG response to several components of $S$ bovis including bands of $66,58,52$ and $4 \mathrm{Kd}$. For $S$ sanguis, there was a strong IgG response to bands of $80-82,76,60$ and $45 \mathrm{Kd}$. These patterns of antibody production were absent in patients with uncomplicated septicaemia and in controls. The delineation of these patterns enabled confirmation of the final diagnosis in seven patients initially suspected of having culture negative endocarditis.

In the United Kingdom there are about 1500 annual cases of infective endocarditis, with an overall mortality of $15-30 \% .{ }^{1}$ In developed countries there has been a decline in the number of cases due to $\alpha$-haemolytic ("viridans") streptococci, which carry a low mortality of $6 \%{ }^{2}$; there has been an increase in the number of cases due to enterococci, especially in the elderly, ${ }^{3}$ with a mortality of about $14 \% .^{2}$ This difference has been partly caused by varying susceptibility to antibiotics. Enterococcus faecalis is tolerant of the bactericidal activity of aminoglycosides, and with cell wall active drugs (such as penicillin or vancomycin) a bacteriostatic action only is observed. ${ }^{4}$ As optimal treatment for infective endocarditis depends on obtaining bactericidal activity in vivo antibiotics must be given in combination, and some of these (such as vancomycin and gentamicin) are synergistically nephrotoxic. ${ }^{5}$

Infective endocarditis is diagnosed by typical clinical signs, supported by vegetations on two dimensional echocardiography. In the early stages the clinical history may be non-specific and the characteristic clinical signs missing so that diagnosis is delayed. Confirmation is made by cultures of blood samples, but these may be negative in up to $10 \%$ of cases $^{2}$ due to previous antibiotic treatment or a fastidious causative organism.

Accepted for publication 21 April 1987
Serological tests recently developed for the diagnosis of culture negative endocarditis have included indirect fluorescence ${ }^{67}$ and enzyme linked immunosorbent assays. ${ }^{8}$ While these tests are useful they have certain limitations. The fluorescence antibody test detects total antibody and may show false positive results in patients with recent infections such as streptococcal throat infections or streptococcal septicaemias. False negative results may occur due to the patients being infected with organisms other than those included in the test. The enzyme linked immunosorbent assay for nutritionally variant streptococci failed to detect antibodies in $26 \%$ of the cases of endocarditis and cross reacted with $7 \%$ of patients with endocarditis infected with another organism. ${ }^{8}$

In this study an immunoblotting technique was applied to the serodiagnosis of enterococcal and culture negative endocarditis. Immunoblotting allows an antibody response to individual streptococcal antigens, previously separated by sodium dodecylsulphate polyacrylamide gel electrophoresis to be examined. The advantage over fluorescence is that the immune response to each streptococcal antigenic band can be examined separately and assayed for IgM and IgG. In patients with clinical evidence of endocarditis this allows the antibody response to be compared and contrasted with the response seen in patients with enterococcal bacteraemia but no evidence of endocarditis. It is clearly advantageous to be 
able to distinguish between septicaemias, which require a relatively short course of antibiotics, and endocarditis, which requires a much longer course and perhaps cardiac surgery.

Antibiotic resistance among the group D streptococci is not uniform. Most isolates of $S$ bovis are susceptible to penicillin, ${ }^{9}$ while the enterococcal species are resistant to this drug. E faecium is generally more resistant to antibiotics than $E$ faecalis. Precise serological diagnosis would therefore improve the chance of choosing appropriate treatment in cases of culture negative endocarditis.

To assess the potential value of immunoblotting sera from patients with endocarditis due to $E$ faecalis, $E$ faecium, and $S$ bovis were tested against extracts from all three species and also against extracts from $S$ sanguis (to estimate the degree of cross reactivity with a viridans streptococcus). Sera were also examined from patients with confirmed endocarditis caused by other species, including viridans streptococci. From these observations it was possible to define species and antibodies specific to endocarditis. The presence of these antibodies was then sought in the sera from seven patients with the clinical features of endocarditis but with negative blood cultures.

\section{Material and methods}

\section{PREPARATION OF ANTIGEN}

Enterococcus faecalis (previously Streptococcus faecalis) NCTC 775, Enterococcus faecium (previously Streptococcus faecium) NCTC 7171, Streptococcus bovis, type 1, NCTC 8133, and Streptoccus sanguis F90A (Perryer) were cultured in Isosensitest broth for 48 hours at $35^{\circ} \mathrm{C}$ in a rotary shaker. $S$ sanguis F90A (Perryer) required the addition of heat inactivated horse serum $(1 \% \mathrm{v} / \mathrm{v})$ for confluent growth.

The cultures were then pelleted by centrifugation at $2500 \mathrm{~g}$ at $4^{\circ} \mathrm{C}$ for 15 minutes, resuspended in $10 \mathrm{~mm}$ Tris-hydrochloric acid (pH 7.4), and then repelleted. This procedure was repeated twice. The organisms were then fragmented in a French press at $4^{\circ} \mathrm{C}$. The disintegrated cells were then centrifuged at $10000 \mathrm{~g}$ for 10 minutes. The supernatant was used in further experiments and stored at $-70^{\circ} \mathrm{C}$. The protein content was measured by the Lowry method. ${ }^{10}$

\section{SODIUM DODECYL-SULPHATE PAGE}

The supernatants were solubilised in $2.6 \%$ sodium dodecyl-sulphate and $1.3 \%$ mercaptoethanol at $100^{\circ} \mathrm{C}$ for five minutes. Electrophoresis of these preparations was carried out with $10 \%$ polyacrylamide gels in a discontinuous buffer system. ${ }^{11}$ Fifty micrograms of protein was applied to each well. Molecular weight standards were: myosin, 200000 ; $\beta$-galactosidase, 116250; phosphorylase B, 92500 ; bovine serum albumin, 66200 ; ovalbumin, 45000 ; 7 carbonic anhydrase, 31000 ; soybean trypsin inhibitor, 21 500; and lysozyme, 14400.

\section{WESTERN BLOTS}

Proteins were transferred ${ }^{12}$ on to nitrocellulose papero in buffer containing $25 \mathrm{mM}$ Tris, $192 \mathrm{mM}$ glycine, 등 and $20 \%$ methanol (pH 8.3). Transfer was performed at $25^{\circ} \mathrm{C}$ with a current of $500 \mathrm{~mA}$ for 30 minutes in a Transphor cell (LKB Laboratories). Free protein sites were saturated by an incubation in $3 \%$ bovine serum ${ }^{\infty}$ albumin (Sigma) in buffered saline $(0.9 \%$ sodium $\vec{O}$ chloride and $10 \mathrm{mM}$ Tris, pH 7.4) at $4^{\circ} \mathrm{C}$ overnight. The nitrocellulose membrane was then incubated at $\omega$ $25^{\circ} \mathrm{C}$ for two hours with the patient's serum diluted $1 / 10$ in $3 \%$ bovine serum albumin and $0.05 \%$ Tween 20 in buffered saline. After washing five times over 30 . minutes in $0.9 \%$ saline and $0.05 \%$ Tween 20 the $\overrightarrow{0}$ nitrocellulose was incubated for one hour at $25^{\circ} \mathrm{C} \overrightarrow{\vec{A}}$ with alkaline phosphatase conjugated antihuman $\vec{C}$ IgM or IgG (Sigma). The conjugate was dilutedo $1 / 1000$ immediately before use in $3 \%$ bovine serum? albumin in buffered saline. After washing, as $\vec{O}$ described above, the nitrocellulose was incubated for 15 minutes at $25^{\circ} \mathrm{C}$ in a freshly prepared and filtered mixture of equal volumes of naphthol AS-MX phos- $\stackrel{-}{-}$ phate (Sigma $0.4 \mathrm{mg} / \mathrm{ml}$ in distilled water) and fast regd $\overrightarrow{0}$ TR salt (Sigma; $6 \mathrm{mg} / \mathrm{ml}$ in $0.2 \mathrm{M}$ Tris, $\mathrm{pH} 8 \cdot 2$ ) . $_{-}^{\circ} \stackrel{-}{-}$ Antibody intensity was compared by eye with that controls whose density had been measured previous with a Joyce Loebl scanning densitometer. The densitometer trace heights were classified as "strong (greater than $100 \mathrm{~mm}$ ) or "weak" (between 5 and 30 응 $\mathrm{mm}){ }^{14}$

\section{TEST SERA}

Controls

"Normal" Serum was obtained from five members of the laboratory staff and from five patients screened in the antenatal clinic for rubella.

Septicaemias and endocarditis Serum was examined from septicaemias due to Pseudomonas aeruginosa, $(\mathrm{n}=2) ;$ Candida albicans $(\mathrm{n}=5) ;$ Klebsiella aero- $\frac{\mathrm{3}}{3}$ genes $(n=2)$; disseminated aspergillosis $(n=3)$; Staphylococcus aureus $(\mathrm{n}=2) ;$ Staphylococcus epider-J midis $(\mathrm{n}=3)$; and a JK corynebacterium $(\mathrm{n}=1)$. Serum was also obtained from a patient with endocarditis due to $S$ aureus and one with endocarditis due $N$ to $S$ epidermidis.

\section{Streptococcal septicaemias}

All patients had at least one set of positive blood cul-O tures, no clinical or laboratory evidence of endo-e carditis, and a fever which responded to the $\Phi$ appropriate antbiotics. There were eight cases caused $\stackrel{\oplus}{?}$ by $E$ faecalis, of which two were fatal, two due to $E$ D faecium, and one due to $S$ bovis (table 1). 
Table 1 Details of 24 patients with streptococcal infection

\begin{tabular}{|c|c|c|c|c|c|}
\hline Case No & Sex & Underlying diagnosis & Blood culture isolate & $\begin{array}{l}\text { Echocardiographic/clinical } \\
\text { evidence of endocarditis }\end{array}$ & Outcome \\
\hline 1 & $\mathbf{F}$ & Subacute bacterial endocarditis* & E faecalis (3) & + & Survived \\
\hline 2 & $\mathbf{F}$ & Subacute bacterial endocarditis* & E faecalis (2) & + & Survived \\
\hline 3 & $\mathrm{M}$ & $\begin{array}{l}\text { Hodgkin's lymphoma, subacute } \\
\text { bacterial endocarditis* }\end{array}$ & E faecalis (2) & + & Survived \\
\hline 4 & $\mathbf{F}$ & Subacute bacterial endocarditis* & E faecalis (2) & + & Survived \\
\hline 5 & $\mathbf{M}$ & Subacute bacterial endocarditis & E faecalis (2) & + & Survived \\
\hline 6 & $\mathbf{F}$ & Aortic valve replacement & E faecalis (1) & - & Survived \\
\hline 7 & $\mathbf{M}$ & Acute myeloid leukaemia & E faecalis (2) & - & Survived \\
\hline 8 & $\mathbf{M}$ & Acute myeloid leukaemia & E faecalis (1) & - & Survived \\
\hline 9 & $\mathbf{F}$ & Acute myeloid leukaemia & E faecalis (1) & - & Survived \\
\hline 10 & $\mathbf{F}$ & Acute myeloid leukaemia & E faecalis (2) & - & Survived \\
\hline 11 & $\mathbf{F}$ & Acute myeloid leukaemia & E faecalis (1) & - & Survived \\
\hline 12 & $\mathbf{F}$ & Diabetic ketoacidosis & E faecalis (2) & - & Died \\
\hline 13 & $\mathbf{F}$ & Acute myeloid leukaemia & E faecalis (1) & - & Died \\
\hline 14 & $\mathbf{F}$ & $\begin{array}{l}\text { Acute myeloid leukaemia, } \\
\text { subacute bacterial endocarditis* }\end{array}$ & E faecium (2) & + & Survived \\
\hline 15 & $\mathbf{F}$ & Acute myeloid leukaemia & E faecium (1) & - & Survived \\
\hline 16 & $\mathbf{M}$ & Non-Hodgkin's lymphoma & E faecium (2) & - & Survived \\
\hline 17 & $\mathbf{M}$ & Alcoholic cirrhosis & $S$ bovis (6) & + & Died \\
\hline 18 & $\mathbf{M}$ & Subacute bacterial endocarditis* & $S$ bovis (2) & + & Survived \\
\hline 19 & $\mathbf{M}$ & Acute myeloid leukaemia & $S$ bovis (2) & - & Survived \\
\hline 20 & $\mathbf{F}$ & Subacute bacterial endocarditis* & $S$ agalactiae (3) & + & Survived \\
\hline 21 & $\mathbf{M}$ & Fallot's tetralogy & $S$ mitis (3) & + & Survived \\
\hline 22 & $\mathbf{M}$ & Subacute bacterial endocarditis* & $S$ mutans (2) & + & Survived \\
\hline 23 & $\mathbf{F}$ & Subacute bacterial endocarditis* & $S$ sanguis (2) & + & Survived \\
\hline 24 & $\mathbf{M}$ & Subacute bacterial endocarditis* & $S$ sanguis (2) & + & Survived \\
\hline
\end{tabular}

*Subacute bacterial endocarditis based on a new cardiac murmur and splinter haemorrhages.

Figure in parentheses is the number of separate sets of blood cultures positive.

\section{Endocarditis}

All patients had at least two sets of positive blood cultures as well as clinical and echocardiographic evidence of endocarditis. There were five cases of $E$ faecalis, one of $E$ faecium, two of $S$ bovis, two of $S$ sanguis, and one each of Streptococcus mitis, Streptococcus mutans, and Streptococcus agalactiae (table 1).

\section{Culture negative endocarditis}

Serum was examined from seven patients in whom a clinical diagnosis of culture negative endocarditis was considered (table 2). In cases 25 to 28 there was a fever of unknown origin and a history of rheumatic fever but no clinical or echocardiographic evidence of endocarditis. In cases 29,30 , and 31 there was clinical evidence of endocarditis but persistently negative blood cultures. In case 29 Alkaligenes denitrificans, the causative organism, was isolated from the valve at operation. In cases 30 and 31 viridans streptococci had been isolated before the start of antibiotic treatment. These isolates had been ignored and discarded before the patient had been referred to the second hospital where the diagnosis of culture negative endocarditis was made. This history was only available after the patient had responded to antibiotics.

\section{Results}

\section{E FAECALIS ANTIGEN}

Immunoblotting sera from patients and controls against $E$ faecalis led to the identification of 19 antigenic bands whose apparent molecular weight varied from 33-112 Kd (table 3). Patients with $E$ faecalis endocarditis had the highest titres of antibody against the greatest number of antigenic bands (fig 1). All five cases had a pronounced IgM response to antigenic bands of molecular weight $112,88-90$, and $45-47 \mathrm{Kd}$ and strong IgG responses to bands of molecular weight 88-90 and $45-47 \mathrm{Kd}$. This pattern of response

Table 2 Details of seven patients with suggested clinical diagnosis of culture negative endocarditis

\begin{tabular}{|c|c|c|c|c|c|}
\hline Case No & Sex & $\begin{array}{l}\text { Fever of } \\
\text { unknown origin }\end{array}$ & $\begin{array}{l}\text { Previous history of } \\
\text { rheumatic fever }\end{array}$ & $\begin{array}{l}\text { Echocardiographic/ } \\
\text { clinical signs of } \\
\text { endocarditis }\end{array}$ & Final diagnosis \\
\hline $\begin{array}{l}25 \\
26 \\
27 \\
28 \\
29 \\
30 \\
31\end{array}$ & $\begin{array}{l}\mathbf{F} \\
\mathbf{M} \\
\mathbf{M} \\
\mathbf{F} \\
\mathbf{M} \\
\mathbf{M} \\
\mathbf{F}\end{array}$ & $\begin{array}{l}+ \\
+ \\
+ \\
+ \\
+ \\
+ \\
+\end{array}$ & $\begin{array}{l}+ \\
+ \\
+ \\
+ \\
+ \\
+\end{array}$ & $\begin{array}{l}- \\
- \\
- \\
+ \\
+ \\
+\end{array}$ & $\begin{array}{l}\text { Carcinoma of ovary } \\
\text { Lymphoma } \\
\text { Hepatoma } \\
\text { Diverticulitis } \\
\text { Alkaligenes denitrificans endocarditis } \\
\text { Streptococcal endocarditis } \\
\text { Streptococcal endocarditis }\end{array}$ \\
\hline
\end{tabular}


1152

Burnie, Holland, Matthews, Lee

Table 3 Details of No of patients in each group whose sera were positive when immunoblotted against $E$ faecalis antigen

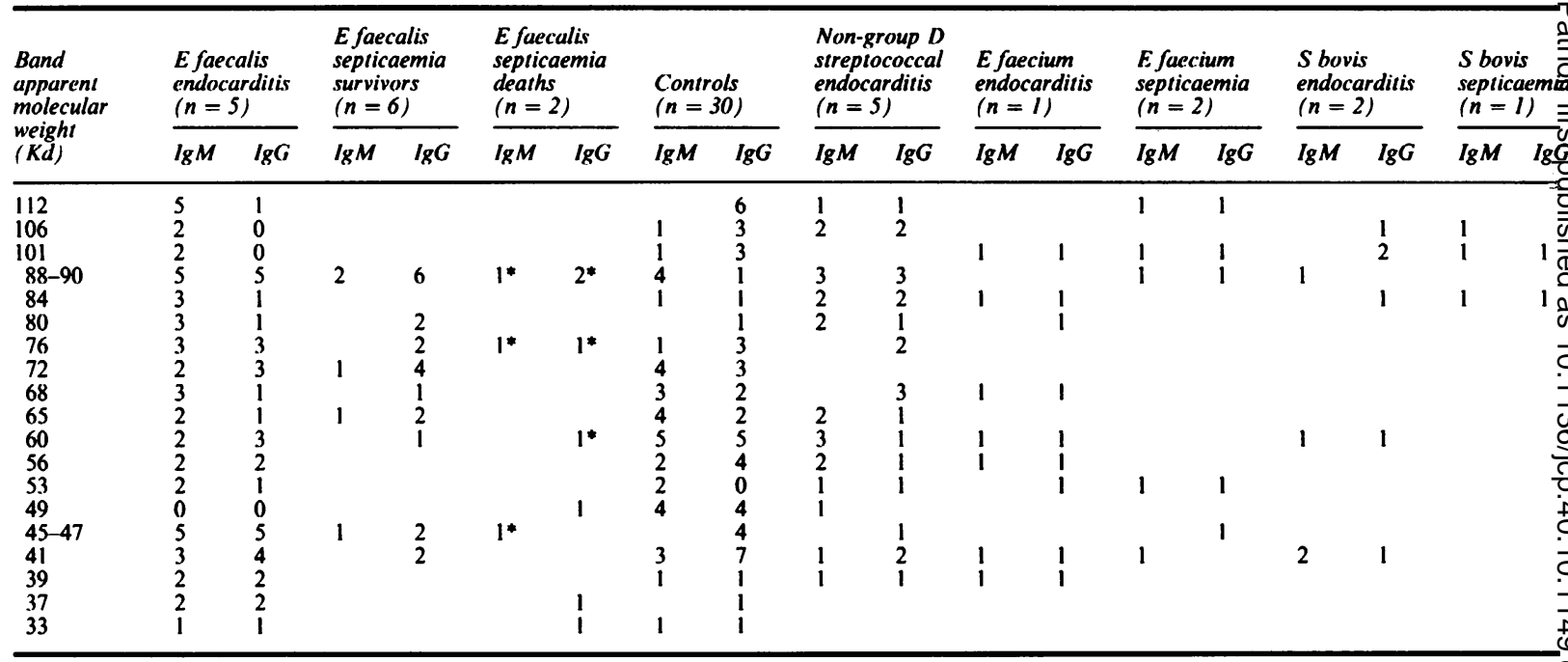

*Trace amount of antibody

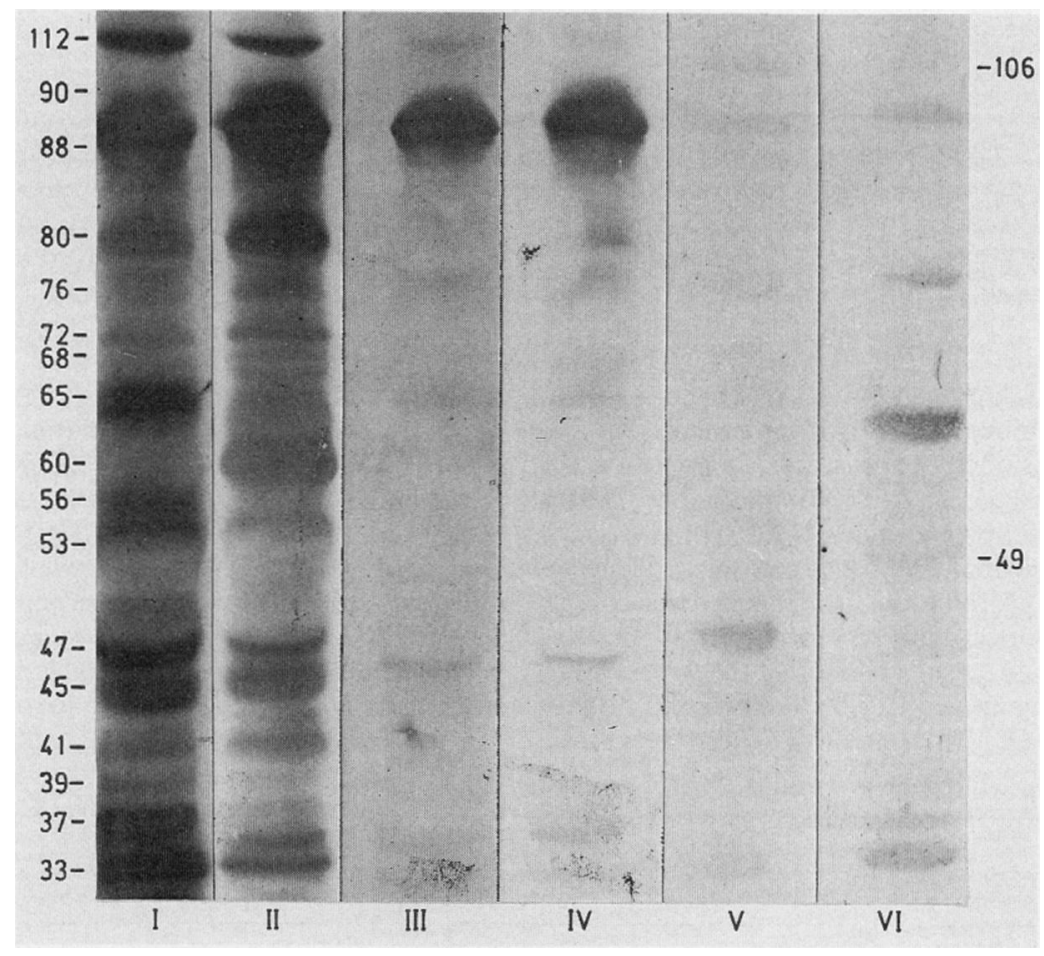

Fig 1 Serum from case 4 (E faecalis endocarditis), assayed against E faecalis antigen preparation and stained for $\operatorname{Ig} M$ (i) and $\operatorname{Ig} G$ (ii); serum from case 6 who survived E faecalis septicaemia, assayed for $\operatorname{Ig} M$ (iii) and $\operatorname{Ig} G$ (iv); serum from case 12 who died from $E$ faecalis septicaemia, assayed for $\operatorname{IgM}(v)$ and $\operatorname{Ig} G(v i)$. 


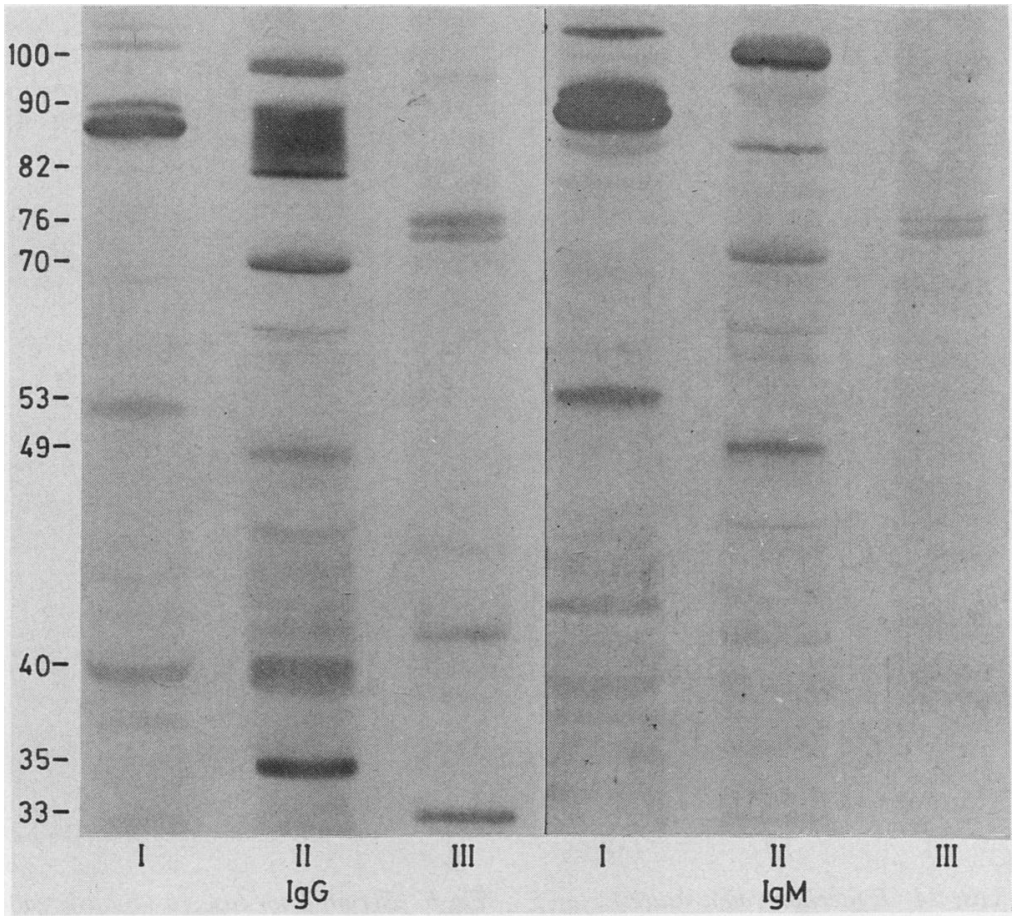

Fig 2 Serum from case 16 ( $E$ faecium septicaemia), assayed for IgM and IgG against (i) $E$ faecalis, (ii) $E$ faecium, and (iii) $S$ sanguis.

was found only in the patients with $E$ faecalis endocarditis, although antibodies against each of the individual antigenic bands were occasionally seen in other patients. All six patients who survived $E$ faecalis septicaemias developed a strong IgG response against the 88-90 Kd molecular weight band (fig 1) but the two fatal cases of $E$ faecalis septicaemia had weak responses which faded terminally (fig 1). Some patients in other groups had an IgG response against this band. Usually this was low titre antibody, but in patients with $E$ faecium infections it could be high (fig 2).

\section{E FAECIUM ANTIGEN}

Immunoblotting serum from patients and controls identified 12 antigenic bands whose apparent molecular weight varied from 35-116 Kd (table 4). In the two patients who survived an $E$ faecium septicaemia and the patient with $E$ faecium endocarditis there was a strong IgG response to bands of 82-90 Kd (figs 2 and 3). High antibody titres against the $82-90 \mathrm{Kd}$ bands were also seen in the patients with $E$ faecalis endocarditis (fig 4) and the patient with $S$ bovis endocarditis (fig 5). Cross reactivity between $E$ faecium and $E$ faecalis was particularly strong, as shown using sera from patients with $E$ faecium and $E$ faecalis endocarditis (figs 3 and 4).
STREPTOCOCCUS BOVIS ANTIGEN

Imunoblotting detected $11 \mathrm{~S}$ bovis antigenic bands whose molecular weight varied from 41-130 Kd (table $5)$. Both the patients with $S$ bovis endocarditis produced strong IgG responses to many bands, including bands of 130, 66, 58, 52 and $41 \mathrm{Kd}$ (fig 5). Some of these antibodies were also seen in the patient who survived uncomplicated $S$ bovis septicaemia, but the total amount of antibody shown against all the antigenic bands was much less.

\section{STREPTOCOCCUS SANGUIS ANTIGEN}

Immunoblotting detected $14 S$ sanguis antigenic bands whose molecular weight varied from 33-108 Kd (table 6). The two patients with $S$ sanguis endocarditis produced a strong IgG response to bands of $80-82,76,60$, and $45 \mathrm{Kd}$. Occasionally antibodies to these bands were also seen at a lower titre in virtually all other groups (table 6), but the combination of a strong IgG response to all these antigenic bands at one time was restricted to the patients with $S$ sanguis endocarditis.

\section{CULTURE NEGATIVE ENDOCARDITIS}

Table 7 summarises the results. This shows which antibody specificities present in the patients with culture positive endocarditis were also present in the 


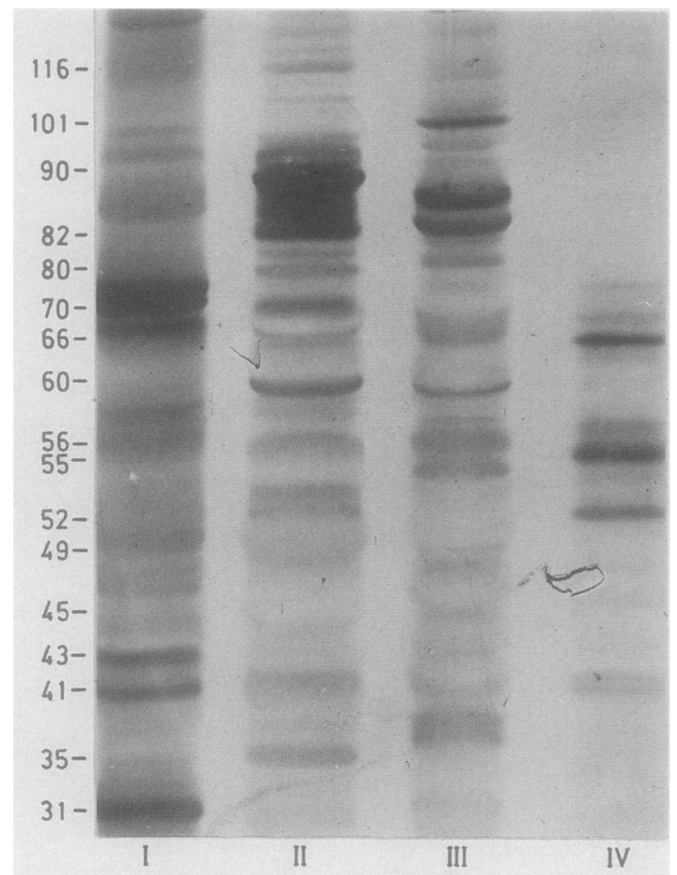

Fig 3 Serum from case 14 (E faecium endocarditis), assayed for IgG against (i) $S$ sanguis, (ii) E faecium, (iii) $E$ faecalis, and (iv) $S$ bovis.

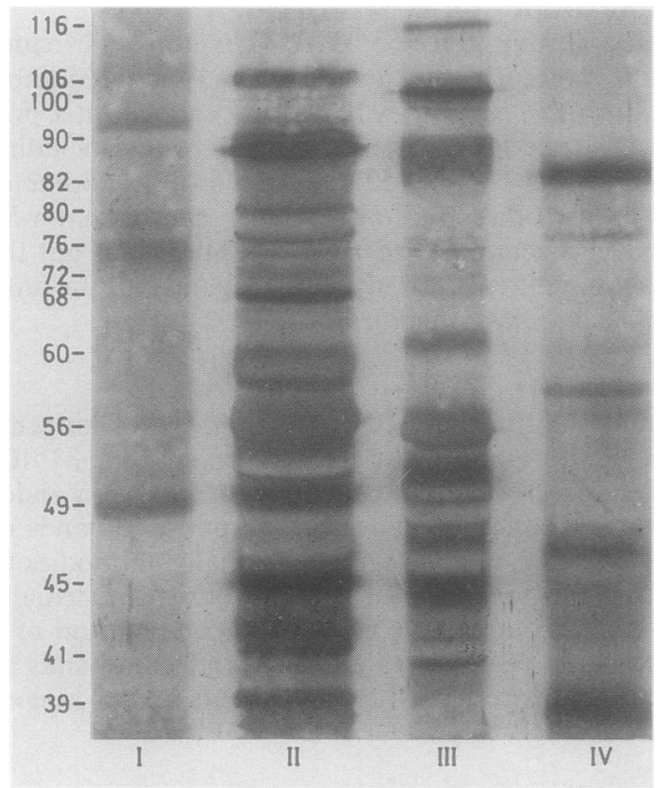

Fig 4 Serum from case 1 (E faecalis endocarditis), assayed for IgM against (i) $S$ bovis, (ii) $E$ faecalis, (iii) $E$ faecium, and (iv) $S$ sanguis.
Burnie, Holland, Matthews, Lee $\stackrel{\varrho}{=}$

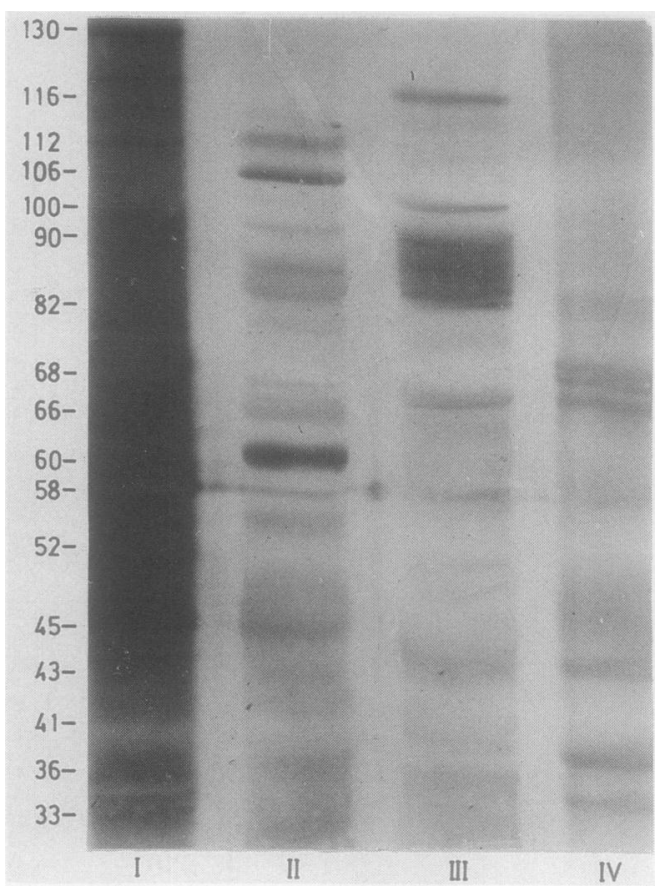

Fig 5 Serum from case 16 ( $S$ bovis endocarditis), assayed $\vec{\omega}$ for IgG against (i) $S$ bovis, (ii) E faecalis, (iii) E faeciur and (iv) $S$ sanguis.

seven patients with a suggested clinical diagnosis of culture negative endocarditis. In the five cases where the final diagnosis was neither enterococcal nor strep- $\stackrel{\mathbb{D}}{0}$ tococcal endocarditis (cases 25-29) no distinctive pat- $\overrightarrow{\overrightarrow{0}}$ tern of antibodies was seen against any of the 3 antigenic extracts tested. Fig 6 illustrates the immunoblots from case 25 . In cases 30 and 31 the finalo diagnosis was endocarditis due to an $\alpha$ viridans Streptococcus. The results from case 30 (fig 7) fit the diag-? nosis of $S$ sanguis endocarditis, with a strong $\operatorname{IgG} 3$ response to bands of $45,60,76$ and $80-82 \mathrm{Kd}$. There was some limited cross reactivity with $E$ faecalis and $\frac{3}{3}$ $E$ faecium. The results from case 31 are less clear as antibody was produced to some of the antigenic $\triangle$ bands, characteristic of endocarditis, due to each of $\frac{7}{0}$ the micro-organisms.

\section{Discussion}

Although the number of patients in each group was small, there were clearly differences in the antigen recognised by sera from the patients in the different groups. Sera from the five patients with $E$ faecalis? endocarditis all had high IgG and IgM antibody titres to bands of 88-90 Kd and 45-47 Kd in the E faecalis antigen preparation and cross reacted with severa菟 
Role of immunoblotting in the diagnosis of culture negative and enterococcal endocarditis

Table 4 Details of No of patients in each group whose sera were positive when immunoblotted against E faecium antigen

\begin{tabular}{|c|c|c|c|c|c|c|c|c|c|c|c|c|c|c|c|c|}
\hline \multirow{2}{*}{$\begin{array}{l}\text { Band } \\
\text { apparent } \\
\text { molecular } \\
\text { weight } \\
(K d)\end{array}$} & \multicolumn{2}{|c|}{$\begin{array}{l}\text { E faecium } \\
\text { endocarditis } \\
(n=I)\end{array}$} & \multicolumn{2}{|c|}{$\begin{array}{l}\text { E faecium } \\
\text { septicaemia } \\
(n=2)\end{array}$} & \multicolumn{2}{|c|}{$\begin{array}{l}\text { Controls } \\
(n=30)\end{array}$} & \multicolumn{2}{|c|}{$\begin{array}{l}\text { Non-group D } \\
\text { streptococcal } \\
\text { endocarditis } \\
(n=5)\end{array}$} & \multicolumn{2}{|c|}{$\begin{array}{l}\text { E faecalis } \\
\text { endocarditis } \\
(n=5)\end{array}$} & \multicolumn{2}{|c|}{$\begin{array}{l}\text { E faecalis } \\
\text { septicaemia } \\
(n=8)\end{array}$} & \multicolumn{2}{|c|}{$\begin{array}{l}S \text { bovis } \\
\text { endocarditis } \\
(n=2)\end{array}$} & \multicolumn{2}{|c|}{$\begin{array}{l}S \text { bovis } \\
\text { septicaemia } \\
(n=2)\end{array}$} \\
\hline & $\operatorname{Ig} M$ & $\operatorname{Ig} G$ & $\operatorname{Ig} M$ & $\operatorname{Ig} G$ & $\operatorname{Ig} M$ & $\operatorname{Ig} G$ & $I g M$ & $\operatorname{Ig} G$ & $\operatorname{Ig} M$ & $\operatorname{Ig} G$ & $\operatorname{Ig} M$ & $\operatorname{Ig} G$ & $I g M$ & $I g G$ & $I g M$ & $\operatorname{Ig} G$ \\
\hline 116 & & 1 & & & 1 & & 2 & 1 & & & & & & 2 & & \\
\hline 100 & & & 2 & 2 & & 5 & 2 & 2 & 5 & 5 & 2 & 2 & & 1 & & \\
\hline $82-90$ & 1 & 1 & & 2 & 3 & 5 & & 1 & 5 & 5 & 1 & 2 & & 2 & 1 & 2 \\
\hline $\begin{array}{l}80 \\
72\end{array}$ & i & 1 & & & 1 & 3 & & & & & & & & & & \\
\hline 70 & 1 & 1 & 1 & 1 & & 1 & & & 1 & 4 & 1 & 3 & & & & \\
\hline 60 & i & $\mathrm{i}$ & & & & 3 & & 1 & 1 & 5 & 1 & 1 & & & & \\
\hline 55 & 1 & i & & & 2 & 1 & 2 & 1 & 4 & 4 & 3 & 2 & & 2 & & \\
\hline 49 & i & i & 1 & 1 & 1 & i & & 2 & 1 & 5 & 1 & 2 & & 1 & & \\
\hline 45 & 1 & & & & 3 & 2 & 2 & 1 & 5 & 3 & 3 & 1 & 1 & & & \\
\hline 40 & i & 1 & 1 & 1 & 2 & 2 & & & 1 & 4 & 2 & 2 & & & & \\
\hline 35 & 1 & 1 & 1 & & 2 & 4 & 1 & 2 & 4 & 4 & 1 & 1 & & 1 & & \\
\hline
\end{tabular}

Table 5 Details of No of patients in each group whose sera were positive when immunoblotted against $S$ bovis antigen

\begin{tabular}{|c|c|c|c|c|c|c|c|c|c|c|c|c|c|c|}
\hline \multirow{2}{*}{$\begin{array}{l}\text { Band } \\
\text { apparent } \\
\text { molecular } \\
\text { weight } \\
\text { (Kd) }\end{array}$} & \multicolumn{2}{|c|}{$\begin{array}{l}S \text { bovis } \\
\text { endocarditis } \\
(n=2)\end{array}$} & \multicolumn{2}{|c|}{$\begin{array}{l}S \text { bovis } \\
\text { septicaemia } \\
(n=1)\end{array}$} & \multicolumn{2}{|c|}{$\begin{array}{l}\text { Controls* } \\
(n=20)\end{array}$} & \multicolumn{2}{|c|}{$\begin{array}{l}\text { E faecalis } \\
\text { endocarditis } \\
(n=5)\end{array}$} & \multicolumn{2}{|c|}{$\begin{array}{l}\text { E faecium } \\
\text { endocarditis } \\
(n=1)\end{array}$} & \multicolumn{2}{|c|}{$\begin{array}{l}\text { E faecalis/ } \\
\text { E faecium } \\
\text { septicaemia } \\
(n=5)\end{array}$} & \multicolumn{2}{|c|}{$\begin{array}{l}\text { Non-group D } \\
\text { streptococcal } \\
\text { endocarditis } \\
(n=2)\end{array}$} \\
\hline & $\lg M$ & $\operatorname{Ig} G$ & $I g M$ & $\operatorname{Ig} G$ & $\operatorname{Ig} M$ & $\operatorname{Ig} G$ & $\operatorname{Ig} M$ & $\operatorname{Ig} G$ & $\lg M$ & $I g G$ & $\operatorname{Ig} M$ & $\operatorname{Ig} G$ & $\operatorname{Ig} M$ & $\operatorname{Ig} G$ \\
\hline
\end{tabular}

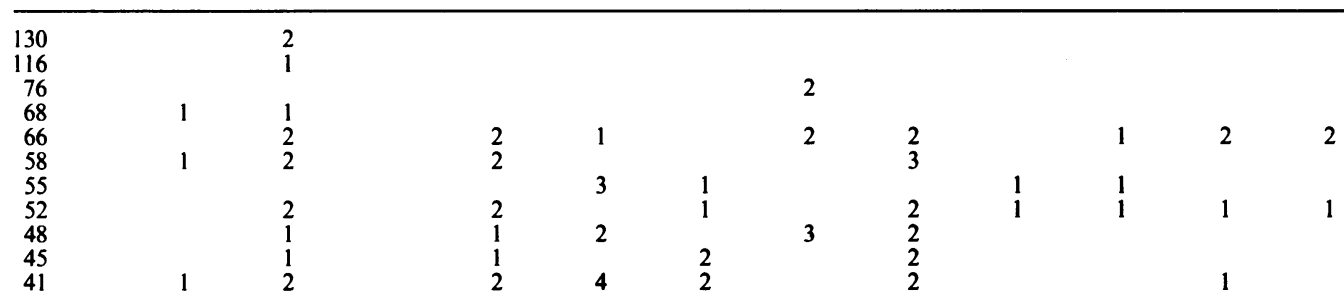

* Sera were no longer available on all of the patients previously included in this group.

Table 6 Details of No of patients in each group whose sera were positive when immunoblotted against $S$ sanguis antigen

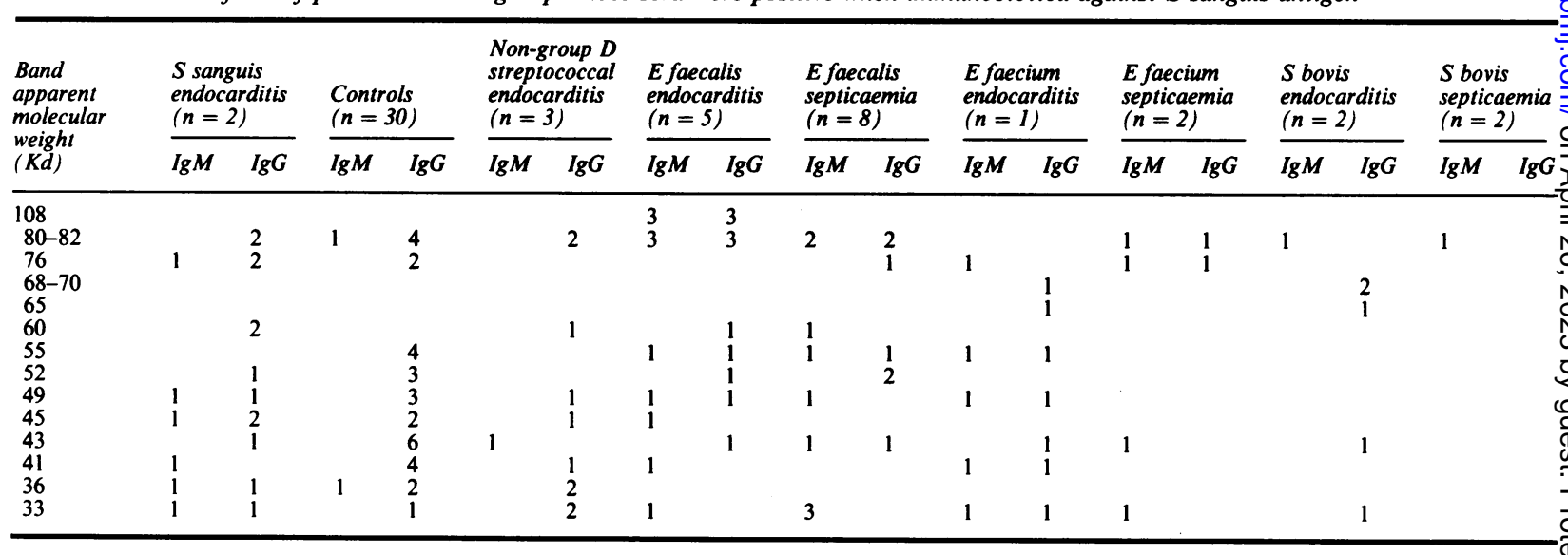


Table 7 Details of antibody responses of seven cases of putative culture negative endocarditis

\begin{tabular}{|c|c|c|c|c|c|c|c|}
\hline \multirow{2}{*}{$\begin{array}{l}\text { Antibody specificities present in } \\
\text { culture positive endocarditis }\end{array}$} & \multicolumn{7}{|l|}{ Case No } \\
\hline & 25 & 26 & 27 & 28 & 29 & 30 & 31 \\
\hline \multicolumn{8}{|l|}{ E faecalis } \\
\hline $\operatorname{lgM} 112,88-90$ and $45-47 \mathrm{Kd}$ & $\begin{array}{l}88-90 \mathrm{Kd} \\
\text { only }\end{array}$ & $\begin{array}{l}88-90 \mathrm{Kd} \\
\text { only }\end{array}$ & - & $\begin{array}{l}88-90 \mathrm{Kd} \\
\text { only }\end{array}$ & - & $\begin{array}{l}45-47 \mathrm{Kd} \\
\text { only }\end{array}$ & - \\
\hline $\operatorname{IgG~88-90,45-47~Kd~}$ & - & - & - & - & - & - & $\begin{array}{l}45-47 \mathrm{Kd} \\
\text { only }\end{array}$ \\
\hline E faecium & & & & & & & \\
\hline IgM 82-90 & - & - & - & - & - & - & - \\
\hline $\begin{array}{l}\text { IgG } 82-90 \\
S \text { bovis }\end{array}$ & - & - & - & - & - & + & + \\
\hline $\begin{array}{l}\text { IgG } 41,52,58,66 \text { and } 130 \mathrm{Kd} \\
S \text { sanguis }\end{array}$ & - & - & - & - & & - & $52 \mathrm{Kd}$ only \\
\hline $\operatorname{IgG} 45,60,76$ and $80-82 \mathrm{Kd}$ & - & - & - & - & - & + & $\begin{array}{l}76,45 \mathrm{Kd} \\
\text { only }\end{array}$ \\
\hline
\end{tabular}

The presence of a strong antibody response against all members of a particular group of antigenic bands is indicated by $(+)$.

bands, including that of $82-90 \mathrm{Kd}$, in the $E$ faecium antigen preparation. Cross reactivity with $S$ bovis and $S$ sanguis was much less. The patient with $E$ faecium endocarditis produced a pronounced IgM and IgG response to the 82-90 Kd component of E faecium and also had antibodics which cross reacted with many $E$ faecalis antigenic bands. Sera from the two patients with $S$ bovis endocarditis recognised bands of $130,66,58,52$ and $41 \mathrm{Kd}$ in the $S$ bovis antigen preparation and showed limited cross reactivity with $E$ faecalis and $E$ faecium. Both patients with $S$ sanguis endocarditis had high titre IgG to bands of $80-82,76$, 60 and $45 \mathrm{Kd}$ in the $S$ sanguis preparation, a response not seen in any of the other patients.

Previous work ${ }^{1516}$ on immunoblotting techniques showed that an IgG antibody response to antigens of 73,40 , and $37 \mathrm{Kd}$ was diagnostic of $E$ faecalis endocarditis. This was based on the observation of these antibodies in six patients with endocarditis due to $E$ faecalis and their absence in cases due to $S$ aureus, $S$ epidermidis, $S$ sanguis (two patients) and $S$ bovis. Antigens were prepared by polyacrylamide gel electrophoresis of whole cells solubilised with sodium dodecyl sulphate. This method of antigen preparation is clearly different from the French pressed cyto-0 plasmic extract used in this study which may explain

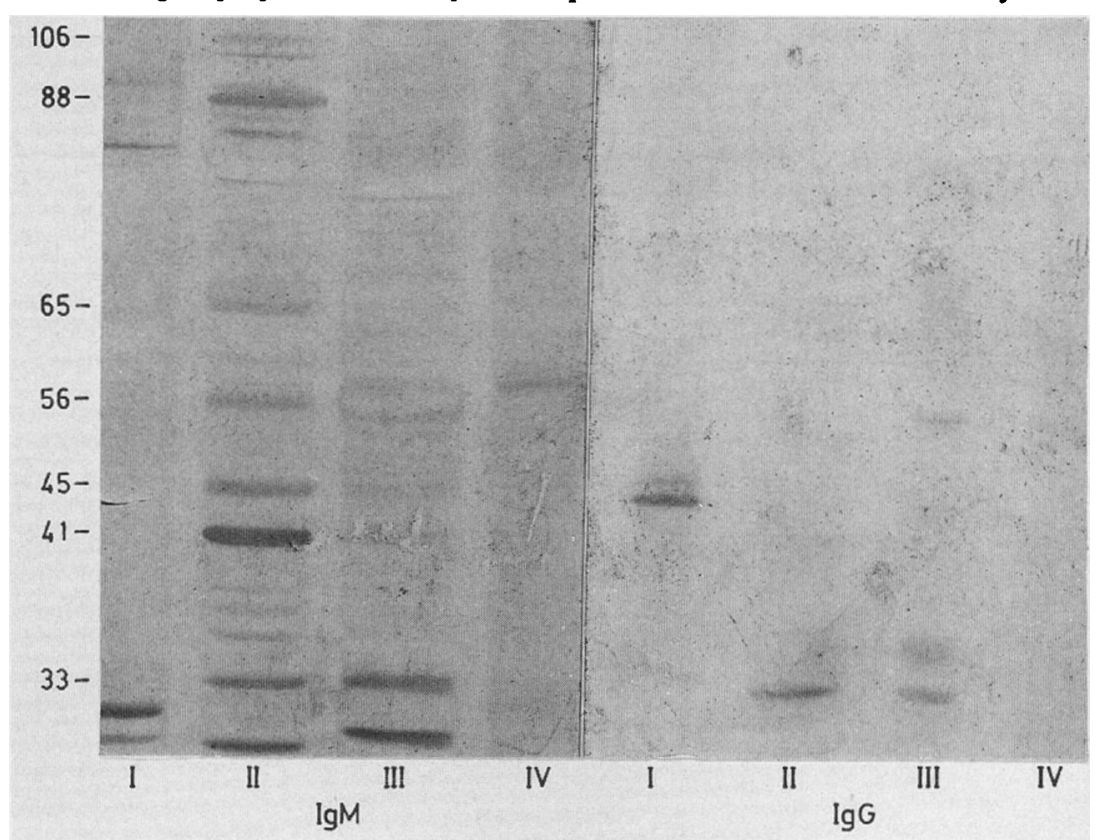

Fig 6 Serum from case 25 with culture negative endocarditis, assayed for $\lg M$ and $\lg G$ against (i) $S$ bovis, (ii) E faecalis, (iii) E faecium, and $S$ sanguis. 


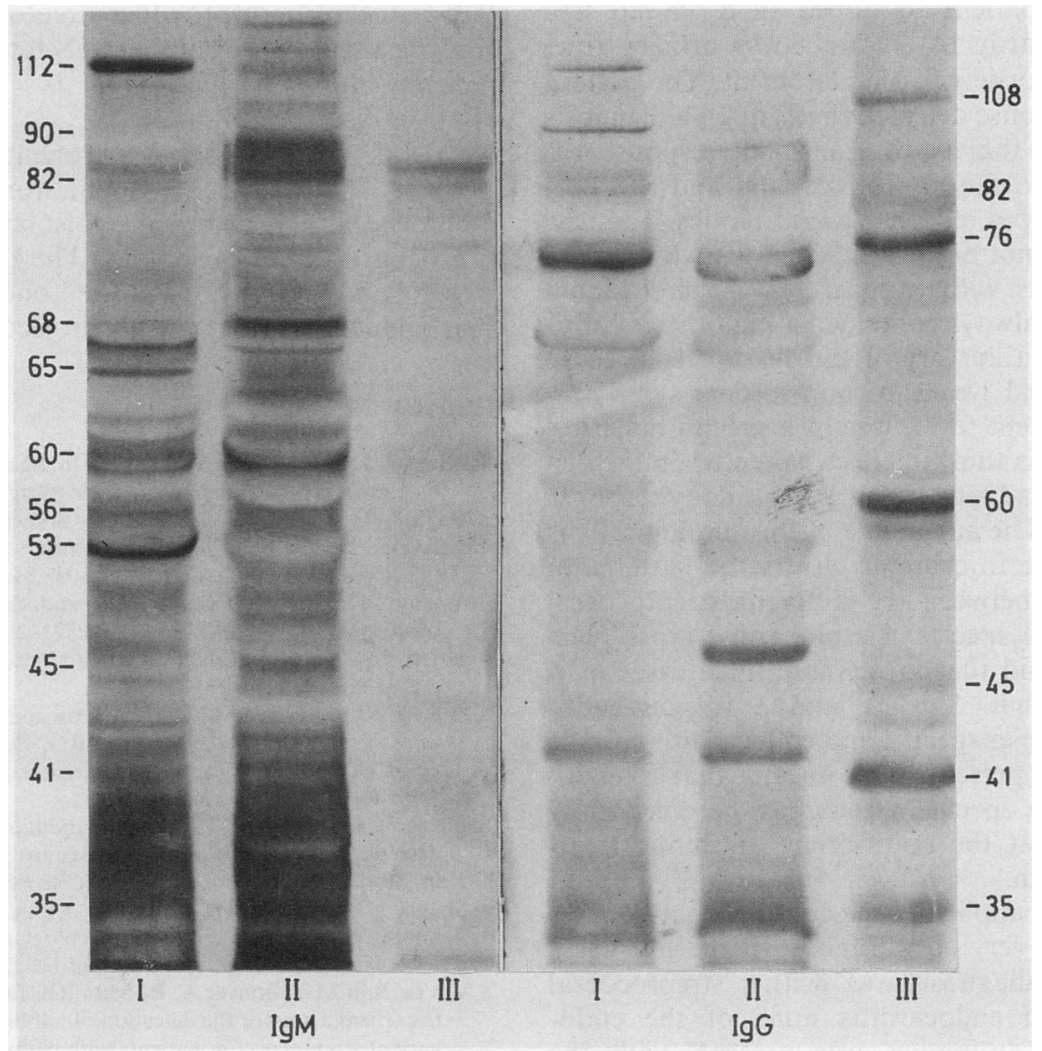

Fig 7 Serum from case 30 (culture negative endocarditis), assayed for $\operatorname{lgM}$ and IgG against (i) E faecalis, (ii) E faecium and (iii) $S$ sanguis.

the variation in results. Lambert et $a l^{16}$ did not attempt to quantify the amount of antibody either against individual antigenic bands or against the total protein extract. Simply categorising the responses into strong, weak, and trace enhances the diagnostic potential of immunoblotting, as antibody was occasionally present against some of the diagnostic antigenic bands in the control sera; but this was usually weak or in trace amounts.

An estimate of the total amount of antibody is valuable. It was found by immunofluorescence ${ }^{7}$ that a titre equal to or greater than $\mathbf{4 0 0}$ when the patient's serum was examined against his or her own isolate was virtually diagnostic of endocarditis. By contrast, five patients with clinically insignificant streptococcal bacteraemias had serum fluorescence antibody titres of only 100 or less. The advantage of immunoblotting over immunofluorescence is that in addition to measuring total antibody, the antibody response to individual antigenic bands can be dissected out. The importance of this is that the appearance of antibody against a particular antigen may signal recovery from a septicaemic episode, rather than persistent infection in the form of endocarditis. If this antibody is measured by immunofluorescence it will produce a high background value, and this may explain the false positive results previously detected in patients with streptococcal septicaemias. ${ }^{7}$ With immunoblotting it was found that patients with endocarditis characteristically had high titre antibody to multiple specific bands at the time of presentation.

This is clearly illustrated by the results obtained for $E$ faecalis. Patients with a septicaemia made a strong IgG response to a band of molecular weight 88-90 $\mathrm{Kd}$. This antibody was either absent or present in much lower titres in the early serum taken before antibiotic treatment. Its appearance coincided with recovery from disease rather than continuing infection as it was only present in trace amounts in the two fatal cases. In the patients with $E$ faecalis endocarditis it was present in high titre but here there were also other antibodies in high titre, including a strong IgM response to bands of 112 and $45-47 \mathrm{Kd}$ and IgG to a band of $45-47 \mathrm{Kd}$. The immunoblot technique therefore allows septicaemia and endocarditis to be distinguished. The clinical value of this was illustrated by 
case 6 where a patient developed an $E$ faecalis septicaemia secondarily to an $E$ faecalis urinary tract infection after aortic valve replacement. The pattern of antibody response detected (fig 1 ) fitted a diagnosis of septicaemia in that a strong antibody response was produced only to the $88-90 \mathrm{Kd}$ band and this correlated with a rapid response to antibiotics. The new aortic valve did not become infected with $E$ faecalis.

In the patients with endocarditis the first serum immunoblotted always contained a high titre of antibody. The natural history of the disease tends to be slow, with several weeks of non-specific symptoms such as intermittent fever, weight loss, and malaise. ${ }^{2}$ This first serum is thus, in effect, taken when the disease is relatively advanced and the antibody response well developed. The advantage of this serologically is that it is possible to examine clearly the patterns of cross reactivity between the different streptococcal and enterococcal species. Despite some cross reactivity it was found that in the confirmed cases of $E$ faecalis, $E$ faecium, $S$ bovis, and $S$ sanguis endocarditis both species specific and endocarditis specific antibodies were present. This means that a endocarditis due to a specific species can be confidently diagnosed so that the appropriate antibiotic treatment can be given.

When this was applied to the culture negative cases the results were very encouraging. In the five cases where the final diagnosis was neither streptococcal nor enterococcal endocarditis none of the endocarditis specific antibodies was present, with the exception of the IgM response to the $88-90 \mathrm{Kd}$ antigen of $E$ faecalis. This was also found in the sera of four of the control patients.

In the two cases with a final diagnosis of streptococcal endocarditis one (case 30 ) fitted exactly the pattern for $S$ sanguis endocarditis. There was a strong IgG response against $S$ sanguis antigen of $45,60,76$ and $80-82 \mathrm{Kd}$. The patient responsed well to treatment with penicillin and gentamicin and did not require valve surgery. The results from case 31 are more difficult to interpret. There was considerable antibody response against $E$ faecium, $S$ sanguis, $S$ bovis, and $E$ faecalis, but no distinctive pattern of antigenic bands was detected by the serum in any of the four antigenic extracts. This suggested that the underlying diagnosis was streptococcal endocarditis due to a species different from those tested.

In conclusion, our results suggest that by using immunoblotting to examine sera from patients with a suggested clinical diagnosis of culture negative endocarditis it is possible to determine whether the patient is likely to have endocarditis due to $E$ faecalis, $E$ faecium, $S$ bovis, or $S$ sanguis. Cases of endocarditis can also be distinguished from septicaemias in culture positive patients. We are now investigating patients with endocarditis due to other streptococcal species to clinically important species.

We thank Dr J Hardie, department of oral micro- $\stackrel{\overrightarrow{\vec{S}}}{\rightarrow}$ biology, The London Hospital, for the supply of 0 streptococcal and enterococcal isolates, Dr JD Ske- 흘 han, department of cardiology, The London Hospital $\frac{\bar{\sigma}}{\partial}$ for sera, and the Trustees of The London Hospital for $\stackrel{\mathbb{Q}}{\mathcal{Q}}$ their financial support of this project.

\section{References}

1 Shanson DC. Infections of the heart. In: Shanson DC, ed. Microbiology in clinical practice. London: Wright PSG, 1982:339.

2 Bayliss R, Clarke C, Oakley CM, Somerville W, Whitefield AGW, Young SEJ. The microbiology and pathogenesis of infective endocarditis. Br heart $J$ 1983;51:339-45.

3 Wesby PD. Streptococcus faecalis endocarditis: an emerging problem? Postgrad Med J 1978;54:321-2.

4 Storch GA, Krogstad DJ. Antibiotic-induced lysis of enterococci. $\vec{A}$ J Clin Invest 1981;68:639-45.

5 Scheld WM, Sande MA. Endocarditis and intravascular infec- 음 tions. In: Mandell GL, Douglas RG, Bennett JE, eds. Prin- ciples and practice of infectious diseases. 2nd ed. New York: John Wiley \& Sons, 1985:564.

6 Shanson DC, Hince D. An immunofluorescent method for 0 detecting endocarditis antibodies against viridans streptococci $\underset{\mathbb{D}}{ }$ in 'Strep viridans' endocarditis. J Clin Pathol 1978;31:292-9.

7 Shanson, Kirk N, Humphrey R. Clinical evaluation of a $\vec{\omega}$ fluorescent antibody test for the serological diagnosis of Strọ $\infty$ tococcal endocarditis. J Clin Pathol 1985;38:92-8.

8 van de Rijn MG, Bouvet A, Roberts RB. Enzyme-linked imm nosorbent assay for the detection of antibodies to nutritionab variant streptococci in patients with endocarditis. $J$ Infect Dis 1986;153:116-21.

9 Moellering RC Jr, Korzeniowski OM, Sande MA, Wennersten ڤે CB. Species-specific resistance to antimicrobial synergism in $S \Omega$ faecium and S faecalis. J Infect Dis 1979;140:203-8.

10 Lowry OH, Rosebrough NJ, Farr AL, Randall RJ. Protein measurement with the folin phenol reagent. J Biol Chem 1981;193:265-75.

11 Laemmli UK. Cleavage of structural proteins during the assembling of the head of bacteriophage T4. Nature 1970;227:680-5.

12 Towbin $\mathrm{H}$, Gordon J. Immunoblotting and dot immunobinding - current status and outlook. J Immunol Methods:1984;72:313-40.

13 O'Connor CG, Ashman LK. Application of the nitrocellulose transfer technique and alkaline phosphatase conjugated anti- $O$ immunoglobulin for determination of the specificity of mono- 3 clonal antibodies to protein mixtures. J Immunol Methods 0 1982;54:267-71.

14 Matthews RC, Burnie JP, Tabaqchali S. Immunoblot analysis of $D$ the serological response in systemic candidosis. Lancet 1984;ii:1415-18.

15 Aitchison EJ, Lambert PA, Farrell ID. Antigenic composition of $\widetilde{N}$ an endocarditis-associated isolate of Streptococcus faecalis and identification of its glycoprotein antigens by ligand blotting with lectins. J Med Microbiol 1986;21:161-7.

16 Lambert PA, Aitchison EJ, Grace Smith EF, Farrell ID Serodiagnosis of Streptococcus faecalis endocarditis. I Infect $<$ 1986;3:309-10.

Requests for reprints to: Dr JP Binnie, Department of $\stackrel{\text { ? }}{+}$ Medical Microbiology, St Bartholomew's Hospital, West $\square$ Smithfield, London EC1A 7BE, England. 